\title{
An Institutional Law Presentation of the European Stabilization Mechanism (ESM) as an Economic Crisis Financial Assistance Instrument
}

\author{
Dimitra Stratigopoulou ${ }^{1} \&$ John Mylonakis ${ }^{2}$ \\ ${ }^{1}$ Vrije Universiteit Bruxelles, Athens, Greece \\ ${ }^{2}$ Economist, Ministry of Finance, Athens, Greece \\ Correspondence: John Mylonakis, 10 Nikiforou str., Glyfada, Athens, 16675, Greece. E-mail: imylon@otenet.gr
}

Received: May 9, 2013 Accepted: May 27, 2013 Online Published: July 5, 2013

doi:10.5539/ilr.v2n1p17 URL: http://dx.doi.org/10.5539/ilr.v2n1p17

\begin{abstract}
EFSM and EFSF were temporarily established for preventing any Euro area Member State's insolvency. The ESM is a permanent mechanism which has common features with the ad hoc mechanism for Greece and the EFSM/EFSF. The purpose of this paper is to assess the effectiveness of ESM as a crisis management mechanism from a law perspective. The comparison between ESM and EFSM/EFSF serve as the basis of this assessment. The paper examines the legal foundation of ESM and the legal nature of the mechanism and presents the decision making process and the actors involved. The new legal basis prescribes that the ESM is activated only when the financial assistance is indispensible for the stability of the euro area as a whole and that the financial assistance is attached to strict conditionality. The contribution to the capital is made by the Euro area Member States, the financial assistance is conditional on a macro-economic adjustment programme and the terms are non-concessional. Although the ESM has a legal basis on European Law it has the legal form of an intergovernmental organisation. The judicial review of ESM was assigned to the European Court of Justice.
\end{abstract}

Keywords: European stabilization mechanism, European financial stabilization mechanism, European financial stability facility, European institutions, economic crisis

JEL Classification Codes: K33, F33, F36

\section{Introduction}

The crisis in the financial markets of U.S.A. in 2008 was just the beginning of the current, global, economic and financial crisis. The countries with high percentages of debt and deficit faced difficulties in borrowing money from the financial markets. In the European Union, Greece was the first country facing borrowing difficulties and calling attention to an urgent solution on European level. A solution on European level is necessary particularly for the Euro area Member States that share a single currency and are bound by the Treaty provisions on the Economic and Monetary Union.

The ad hoc mechanism for Greece was the first reaction to the economic crisis in the Euro area. The economic crisis deepened; soon Ireland and Portugal were in need for urgent financial assistance as well. The establishment of ad hoc mechanisms for all distressed Member States would be time-consuming under these urgent circumstances. On May 7, 2010 the Member States decided to "create a robust framework for crisis management, respecting the principle of Member States' own budgetary responsibility" (Note 1). On May 9, 2010 the Member States "decided to establish a European stabilisation mechanism. The mechanism is based on Art. 122.2 of the Treaty and an intergovernmental agreement of Euro area Member States" (Note 2). The two financial mechanisms are the European Financial Stabilisation Mechanism (EFSM) and the European Financial Stability Facility (EFSF).

The Member States established two different financial mechanisms which are both along the same lines with the ad hoc mechanism for Greece. They both provide financial assistance to the distressed Euro area Member States. The financial assistance is conditional on the Member State's compliance with a macroeconomic adjustment programme. The financial instruments are non-concessional so that the beneficiary Member State has the incentive to regain access to the markets as early as possible. The two mechanisms differ in their institutional structure. EFSM is a European institution which administers European resources (€60 billion, Note 3) whereas 
EFSF is an intergovernmental institution which administers capital contributed by the EFSF Members ( $€ 440$ billion, Note 4). To date EFSM and EFSF have provided financial assistance to Ireland, Portugal and Greece (Note 5).

The difficulty of obtaining sustainable government financing via the financial markets became apparent in other Member States like Italy, Spain and Cyprus. The Euro area Member States assessed the effect of a request for financial assistance by the aforementioned Member States. In financial terms speaking, it was questionable whether and to what extent the remaining resources of EFSM and EFSF were adequate to support the economies of two big Member States like Italy and Spain (Note 6). Legally speaking, EFSM and EFSF were temporarily established for preventing any Euro area Member State's insolvency. The prolongation of these mechanisms would have raised the question of legality of the mechanisms. The EFSF is in operation explicitly for three years until June 30, 2013 (Note 7). The EFSM's legal basis was the exceptional circumstances prescribed in Article 122:2 TFEU. By definition the exceptional circumstances could not be prolonged indefinitely. The establishment of a new mechanism was necessary.

On March 25, 2011 "recalling the importance of ensuring financial stability in the Euro area, the European Council adopted the decision amending the TFEU with regard to the setting up of the European Stability Mechanism (ESM)" (Note 8). The ESM is a permanent mechanism which has common features with the ad hoc mechanism for Greece and the EFSM/EFSF. The contribution to the capital is made by the Euro area Member States, the financial assistance is conditional on a macro-economic adjustment programme and the terms are non-concessional. The Euro area Member States signed the international agreement on the establishment of ESM on February 2, 2012 Note 9). The permanent mechanism was established two years after the first ad hoc mechanism for Greece. The experience of the previous mechanisms could be used as a tool for the Member States to fix the deficiencies of the mechanism and increase its effectiveness.

The purpose of this paper is to assess the effectiveness of ESM as a crisis management mechanism from a law perspective. The comparison between ESM and EFSM/EFSF serve as the basis of this assessment. The paper examines the legal foundation of ESM and the legal nature of the mechanism and presents the decision making process and the actors involved. The analysis is confined in the institutional structure of the ESM while the relevant economic and political aspects of the ESM are beyond the scope of this paper.

\section{Legal Foundation}

The acts which establish the financial mechanisms differ in their legal nature. The EFSM is established by a Union act while the EFSF and the ESM are established by an act of the Member States. Every act of the Union shall be prescribed in a rule of the Treaties (Article 5:2 TFEU). Such a rule is the legal basis of an act; in other words the rule legitimates the act and prescribes the competences of the Union. Competences not conferred upon the Union in the Treaties remain with the Member States which act outside the Union's framework. The Member States' acts shall be in consistency with the policies set out in the EU Treaties. When the Member States' competences are prescribed in the Treaties, the Member States are confined to exercise them as prescribed.

\subsection{Legal Foundation of the EFSM/EFSF}

On May 9, 2010 the Member States "decided to establish a European Stabilisation Mechanism (Note 10). The mechanism is based on Art. 122.2 of the Treaty and an intergovernmental agreement of Euro area Member States" (Note 11). The European stabilisation mechanism was institutionalized in two mechanisms, the EFSM and the EFSF. The establishment of two financial mechanisms corresponds to the two different resources of financial assistance, which are the Union resources ( $€ 60$ billion) and the additional contributions by the Member States ( $€ 440$ billion). The EFSM provides the Union financial assistance under the requirements of Article 122:2 TFEU whilst the EFSF provides the additional financial assistance based on an international agreement of the Member States.

Article 122:2 TFEU prescribes the requirements for the Union financial assistance and the competent institution to grant it: "Where a Member State is in difficulties or is seriously threatened with severe difficulties caused by natural disasters or exceptional occurrences beyond its control, the Council, on a proposal from the Commission, may grant, under certain conditions, Union financial assistance to the Member State concerned. The President of the Council shall inform the European Parliament of the decision taken". The sovereign debt crisis in euro area Member States was a signal that a number of Member States might have to resort to the Union financial assistance. The Council included rules for providing Union financial assistance in the Council Regulation (EU) 407/2010 of 11 May 2010 establishing a European Financial Stabilisation Mechanism (EFSM). 
The EFSM Regulation is a non-legislative act which was adopted by the Council on a proposal from the Commission. The Council adopted the Regulation with qualified majority (Note 12) according to Article 16:3 TEU and in absence of a special voting rule of Article 122:2 TFEU. The European Parliament was informed by the President of the Council. Article 122:2 TFEU does not prescribe competences to the European Parliament and hence prevents the European Parliament deciding against financial assistance. The European Parliament's involvement enhances a Union act's democratic legitimacy. Though the lack of involvement of the European Parliament provides little democratic accountability to the mechanisms, one could argue such a 'sacrifice' is needed in order to ensure effective decision making in times of economic distress.

The exceptional circumstances for the Union financial assistance are prescribed in Article 122:2 TFEU. The beneficiary Member States shall i) be in or be seriously threatened by severe difficulties which ii) are caused by (natural disasters) or exceptional circumstances beyond their control. The sovereign debt crisis of the Member States falls within the requirement of difficulties under Article 122:2 TFEU. The Euro area Member States with high percentages of debt and deficit face difficulties in borrowing money from the financial markets and are at risk of insolvency. The Article 122:2 TFEU qualifies further the term "difficulties".

The Member States' difficulties must also qualify as exceptional circumstances beyond the Member States' control. The assessment whether a sovereign debt crisis is beyond the control of the distressed Member State is ambiguous. The EFSM Regulation interprets the requirements of Article 122:2 TFEU. The EFSM Regulation recognizes firstly that the Member States' economic difficulties are likely to occur due to "the serious deterioration in the international economic and financial environment". The exceptional character of these difficulties is highlighted by the use of the word "unprecedented" and the phrase "beyond what can be explained by economic fundamentals" (Note 13). The EFSM Regulation looks at the Member States' sovereign debt crisis within the contract of the global financial framework and recognizes that the borrowing difficulties are partly attributable to the global economic and financial downturn.

The assessment that the borrowing difficulties are wholly attributable to the Member States' internal policies is supported by the German Constitutional Court. In particular, the German Constitutional Court held that "the indebtedness of Greece and other countries is not particularly a natural disaster similar event, but rather the result of a financial policy for the countries concerned are solely responsible contractually" (Note 14). Under this interpretation of Article 122:2 TFEU the distressed Euro area Member States are not entitled to Union financial assistance. Following this conclusion, the mechanisms set up to provide the financial assistance to the distressed Member States may not do so legally. This assessment undermines the credibility of the mechanism and consequently reduces its effectiveness.

The criticism on the EFSM's legal basis also concerns the EFSF, though Article 122:2 TFEU is not explicitly referred to as the legal basis of the EFSF. The Council decided the establishment of EFSF by an international agreement between Euro area Member States for the coordination of the additional contributions for the financial assistance (Note 15). Preamble one of this agreement states that it "financially supports euro-area Member States in difficulties caused by exceptional circumstances beyond such euro-area Member State's control with the aim of safeguarding the financial stability of the euro area as a whole and of its Member States" (Note 16). Thus the EFSF's purpose is identical with the EFSM's legal basis (Article 122:2 TFEU).

The Council's decision to establish EFSF outside the Union's processes was debatable. From an ideological aspect the Council's decision was contested for its retrogression from European integration. The EFSF came shortly after the entry into force of the Lisbon Treaty. The Lisbon Treaty enhances the supranational elements of the union (Note 17) and it is widely regarded a step towards further European integration. The sovereign debt crisis management by the Council partly outside the Union's processes puts into question the trust into supranational solutions. As the Member of European Parliament Elisa Ferreira stresses: "We need a European dimension rather than a dimension that allows for all kinds of distortions and some countries to control others" (Note 18).

However, the fact that the EFSF was established outside of the Union did not only raise concerns regarding European integration. Member of the European Parliament, Guy Verhofstadt, pointed out that the EFSF was not achieving the same results as the Community mechanism EFSM: "on 6 January, the European financial stabilisation mechanism (EFSM), which is managed by the Commission, issued EUR 5 billion of bonds onto the market over five years. On 25 January, the European Financial Stability Facility, which is intergovernmental, did the same, also for EUR 5 billion and also over five years. The bonds that were managed by the Commission were issued at $2.5 \%$ and those that were managed by the intergovernmental system were put on the market at $2.89 \%$. That means that the EFSM, which is managed under the Community method, is issuing bonds at lower 
interest rates than the intergovernmental system. I wanted to make this point because it is important to show that the Community method has much better outcomes than the intergovernmental system does" (Note 19).

The point Verhofstadt seems to make here is that the lower interest rate which the EFSM commands is to be explained by the increased amount of trust the financial markets have in a solution with the full backing of the Union.

The euro area Member States aimed at having the entire control over EFSF; on that account the EFSF was established as a Special Purpose Vehicle. The Special Purpose Vehicle is a limited liability company (Société Anonyme). The EFSF's shareholders are the Euro area Member States according to their contributions on the basis of their respective ECB capital key. The EFSF is incorporated in Luxembourg and is governed by English law (Note 20). The euro area Member States established the EFSF outside the Union's processes; however the Member States' acts shall be in consistency with the policies set out in the EU Treaties. The establishment of the financial mechanisms shall be in consistency with the rules of the economic and monetary Union where the euro area Member States participate.

The EFSF's and the EFSM's consistency with the rules of the economic and monetary Union and in particular with Article 125 TFEU was arguable. Article 125 TFEU provides that "the Union [...] or a Member State shall not be liable for or assume the commitments of central governments". The meaning of Article 125 TFEU is that each Member State is responsible for its own public finance (Note 21). The Union and the Member States (via EFSM/EFSF) provide financial assistance to the Euro area Member States which face difficulties in borrowing money. This financial assistance enables the distressed Member States to meet their payments. The distress Member State then draws its economic policy counting on this financial assistance. The financial assistance to the distressed Member State (provided in Article 122:2 TFEU) to the extent that carries the risk of moral hazard is prohibited by Article 125 TFEU (Note 22). It has been argued that by providing financial assistance the risk of Member States pre-emptively relying on this assistance is increased, thereby removing the incentive for Member States to adhere to prudent financial rules. The assumption that the financial assistance is illegal under Article 125 TFEU weakens the credibility and the effectiveness of the mechanism.

However, by taking a closer look at the conditions for financial assistance, such an assumption can be dismantled. The financial assistance is granted to the Member States under exceptional circumstances. The design of the financial mechanisms ensures that the financial assistance is granted to the Member States only as long as the exceptional circumstances last. The financial assistance is provided under non-concessional conditions so that moral hazard is avoided. The compliance with the conditions is regularly monitored by the Member States (via EFSM/EFSF) so that the risk of a default is eliminated (Note 23). Under this interpretation the financial assistance via EFSM/EFSF is not contrary to the rule of Article 125 TFEU.

The controversy regarding the EFSM's legal basis (Article 122:2 TFEU) and the consistency of EFSM and EFSF with Article 125 TFEU puts into question the legality of the mechanisms. The controversy on the legality of the financial mechanisms did not have legal consequences so far but it did have political ones. From a legal aspect, the legality was not challenged by an action lodged with the European Court of Justice. An ECJ's judgment would have provided clarity on the validity of the financial mechanisms under European Law (Note 24). From a political aspect, the Heads of State or Government had difficulties in getting the public opinion on their side (and in Germany even the constitutional institutions). Furthermore the debate on the EFSF's intergovernmental nature raised the question of reforming the financial mechanisms. The above issues led to the Member States trying to reinforce the credibility of the system of financial assistance by establishing a new financial mechanism which would replace EFSM and EFSF and eliminate their deficiencies.

\subsection{Legal Foundation of the ESM}

The establishment of the ESM was preceded by a political decision by the European Council. The European Council concluded at its meeting on 28-29 October 2010 that "Heads of State or Government agree on the need for Member States to establish a permanent crisis mechanism to safeguard the financial stability of the Euro area as a whole" (Note 25). The European Council also reached political consensus concerning the legal basis of the permanent mechanism and in particular concerning a "limited treaty change required to that effect, not modifying article 125 TFEU ("no bail-out" clause)".

\subsection{The Creation of a New Legal Basis}

The Member States decided that there shall be a new legal basis for the permanent mechanism. The legal basis of the ESM's predecessors was expressly abandoned "As this mechanism is designed to safeguard the financial stability of the Euro area as a whole, the European Council agreed that Article 122(2) TFEU will no longer be 
needed for such purposes" (Note 26). Article 122:2 TFEU provides for the Union financial assistance in individual Member States. A Member State benefits from the Union financial assistance when it is under exceptional circumstances similar to natural disasters. These exceptional circumstances concern the individual Member State and they are bound to last shortly. The financial stability of the euro area as a whole demands a systemic approach. The Member States shall create a legal basis for the systemic response to the financial crisis in the euro area.

The Head of States or Governments were hesitant to initiate a Treaty reform. The proposal for a Treaty reform came a few months after the lengthy revising of the Treaties and the entry into force of the Lisbon Treaty (Note 27). The hesitation was set aside in view of the ongoing financial crisis on the Euro area. The creation of a legal basis for the systemic response to the financial crisis was urgently needed. The European Council decided on a limited Treaty change. The word "limited" in the European Council conclusions of 28-29 October 2010 implied that the Member States would revise the Treaty with the simplified revision procedure. The European Council expressly decided on this at its meeting on 16-17 December 2010 (Note 28). European Commission's President José Barroso commented in his speech to the European Parliament that the decision is "essential in order to confirm our determination to defend our common currency and to guarantee sound financial stability. The current policies are not sufficient" (Note 29).

The simplified revision procedure was introduced by the Lisbon Treaty in Article 48:6 TEU. This procedure is available for changes in part three of the TFEU under the fundamental condition that the Member States will not increase the powers of the Union. The advantage of the simplified procedure is that it is shorter than the ordinary procedure (Article 48:2-5 TEU). The Convention and the Intergovernmental Conference is omitted. The procedure can still be a long one taking into account the requirement of the reform's approval by the 27 Member States according to their constitutional requirements. The Treaty reform was decided by the European Council on 25 March 2011. By 6 July 2012, parliamentary procedures have been concluded in 21 Member States (Note 30).

The resort to the accelerated procedure of Article 48:6 TEU reflects that the Union involvement to the financial crisis management is not increased (Note 31). Particularly, the Member States agreed on the following addition of paragraph 3 on Article 136 TFEU: "The Member States whose currency is the euro may establish a stability mechanism to be activated if indispensable to safeguard the stability of the euro area as a whole. The granting of any required financial assistance under the mechanism will be made subject to strict conditionality" (Note 32). Legally speaking, Article 136:3 TFEU is rather recognition of the competences which the Member States already have than a breakthrough to the assignment of new competences (Note 33). Article 136:3 TFEU codifies the practice followed by the Member States in the establishment of EFSF. Politically speaking, Article 136:3 TFEU the Member States can invoke that the financial crisis management by the financial mechanisms is consistent with the European law.

The ESM did not escape the criticism for its establishment. Thomas Pringle, a Member of the Irish Parliament, contested on the Irish Courts the consistency of ESM with the European law. On 31 July 2012 the Irish Supreme Court asked for a preliminary ruling (under Article 267 TFEU) from the European Court of Justice on whether European Council Decision 2011/199/EU of 25th March 2011 on the establishment of ESM is valid, whether a euro area Member State is entitled to enter into and ratify an international agreement such as the ESM Treaty and whether the entitlement of a Member State to enter into the ESM Treaty is subject to the entry into force of the Council Decision of 25th March 2011 (in case that the latter is valid, Note 34). The European Court judgment is expected with great interest (Note 35).

\subsection{The Rule of the Legal Basis}

The competence for the establishment of the financial mechanism lies with the Member States. The Member States act outside the Union's framework. The Member States' action shall be in consistency with the economic and monetary Union. In particular when the Member States' actions are prescribed in a Treaties' provision, the Member States are confined to exercise their competence as prescribed. The Member States established the ESM by an international agreement. The establishment of ESM is prescribed in Article 136:3 TFEU. The Member States are bound by the requirements of Article 136:3 TFEU in the ESM's establishment.

Article 136:3 TFEU contains two requirements for the establishment of the ESM: (a) ESM is activated only when the financial assistance to a distressed Member State is indispensible for the stability of the Euro area as a whole and (b) the financial assistance is available to this Member State under strict conditionality. The first requirement reflects the aim of Article 136 TFEU which is to "ensure the proper functioning of economic and monetary union". The financial assistance to a euro area Member State is legitimate under Article 136:3 TFEU 
in so far as it contributes to the strengthening of the economic and monetary policy of the Euro area. The second requirement safeguards the mandate of Article 125 TFEU. The Member States explicitly agreed that "limited treaty change required to that effect, not modifying article 125 TFEU ("no bail-out" clause)". Article 125 TFEU prohibits the financial assistance which results in the assumption of one Member State's liabilities by other Member States. The conditionality to the financial assistance ensures that the Member State will achieve economic recovery and will come up to its financial liabilities.

The requirements of Article 136:3 TFEU set the framework for the establishment of the ESM. The ESM was established by an international agreement between the euro area Member States which makes an explicit reference to Article 136:3 TFEU. Although ESM has a legal basis on European law, ESM is an international financial institution (Article 1:1 ESM). Under public international law (Note 36), the ESM statute shall be ratified by the contracting parties before entering into force. Article 48:1 ESM provides that the ESM will enter into force once Member States representing $90 \%$ of the contributed capital have ratified the statute. Initially the deadline for the ratification process was on January 1, 2013 (Note 37), however the Member States accelerated the national processes due to the urgency of the financial assistance (Note 38). ESM's entry into force is estimated in the end of July 2012 (pending the ratification of Italy) ESM is also open for accession to the Member States which adopt the Euro as their currency (Articles 2, 44 ESM).

On the one hand, the ESM's intergovernmental form makes the procedures for the financial assistance flexible. The euro area Member States have the entire control over the decision-making on the financial assistance (Note 39). The European Parliament's scrutiny does not preclude a quick decision by the euro area Member States. Furthermore, the supranational European institutions (the European Commission, the European Parliament) are not competent to lodge an action for the judicial review of the ESM's decisions (Note 40). This is an exclusive competence of the euro area Member States (Article 37:3 ESM).

The ESM's intergovernmental nature received the same criticism as the EFSF's for their establishment outside the Union's processes. The choice of the intergovernmental form shakes the confidence in the powers of the supranational institutions (Note 41). The Commission's and the European Central Bank's role in the ESM is limited to operational tasks upon the mandate of the Eurogroup which is the decision-making body of ESM. The European Parliament is not involved in any of the procedures under ESM. The pro-European Member of the European Parliament, Guy Verhofstadt, described the financial mechanisms' establishment outside the Union's processes as a crisis of EU governance: "What we are currently experiencing is not, in my opinion, a monetary crisis in the Union, it is not even a crisis of our single currency; rather, it is a crisis of EU governance. This is the situation we are in at the moment. I would even go as far as to say that it is a crisis borne of the Member States' obsessive belief that they can solve Europe's problems with their intergovernmental approach, when a monetary area, Mr President, must be governed by a single method, by the Community method, on the basis of the European interest, and not by a syndicate of national interests, which is what the European Council and the Council of the European Union, by their very nature, represent" (Note 42).

\section{Decision Making}

Every institution has bodies which take decisions for fulfilling the institution's purposes. The financial mechanisms have a decision-making body which grants the financial assistance. Also they have bodies which are tasked with the execution of the decisions. The decision-making bodies' composition and powers determine the governance of the financial mechanisms. The European institutions are part of the decision-making bodies of the financial mechanisms. They have different functions depending on the legal nature of the financial mechanism. For example the European Commission has broader functions in the EFSM which is a European institution than on EFSF and ESM which are intergovernmental institutions.

\subsection{Political Decision-Making Bodies}

The EFSM's decision-making body is the Council. The Council is composed by the ministers of finance of the 27 Member States. The Council's main competence is granting the Union financial assistance to the distressed euro area Member States (Article 3 EFSM). The Council takes this decision by qualified majority. The EFSF's decision-making body is the Eurogroup. The Eurogroup is composed by the ministers of finance of the euro area Member States. The Eurogroup's main competence is approving the Financial Assistance Facility Agreements between EFSF and the beneficiary Member State which include the terms and conditions for the financial assistance (Article 2(1) (a) (iii) EFSF). The unanimity voting rule is inferred by the wording of the provision "such Financial Assistance Facility Agreements [...] shall be approved by the euro-area Member States".

The ESM's decision-making body is the Board of Governors. The Board of Governors is composed by the ministers of finance of the Euro area Member States (Eurogroup). It is chaired by the President of the Eurogroup 
or a President elected by the Eurogroup (Article 5:1 ESM). It is the political body of ESM i.e. it takes decisions which define the ESM policy on whether and under what conditions the financial assistance is granted to the Applicant State [Article 5(6)(f) ESM]. The Board of Governors takes the decision for granting financial assistance by mutual agreement (unanimity) (Article 5:6 (f) ESM).

The EFSM's decision-making body is broader than the EFSF's and ESM's decision-making bodies. EFSM is a Union institution which operates the financial assistance by the Union budget. It is not surprising that the Union financial assistance is allocated by all the Member States in the Council. The qualified majority voting rule mitigates the Member State's power to block a decision. The EFSM's decision-making body ensures the unity in addressing the issues within the European Union. However, it bears the risk that a group of Member States not belonging to the euro area can block the financial assistance to a distressed euro area Member State.

Obviously the source of the financial assistance determines the actor empowered with the decision-making in the financial mechanisms. The EFSF and ESM are intergovernmental institutions which operate the financial assistance by the contributions of their members. Their decision-making bodies consist of fewer members (the euro area Member States) who act on the best interests of the Monetary Union. This makes them more flexible into decision taking than the Council which has to safeguard the interests of the Union as a whole. Taking into account the effectiveness criterion, the EFSM's Union model dropped in the adoption of the EFSF's intergovernmental model of decision-making by the ESM drafters.

\subsection{Executive Bodies}

There is no explicit rule on the hierarchy among the bodies of the financial mechanisms. The hierarchy is inferred by the powers of each body. Next to the decision-making bodies there are bodies which carry out the operations of each financial mechanism (which are named executive bodies to be distinguished from the political bodies in this chapter).

The EFSM's executive body is the Commission. The Commission is a Union institution which is composed by technocrats and safeguards the interests of the Union as a whole. The Commission is competent to contract the borrowing in the financial markets, conclude the terms and conditions for the financial assistance and monitor their implementation by the beneficiary Member State (Articles 2, 3:5 EFSM). The Commission cooperates closely with other European institutions like with the ECB and, where necessary, with the Economic and Financial Committee.

The EFSF's structure includes the Eurogroup Working Group and the Commission. The Eurogroup Working Group, which is composed by senior officials from national ministries or relevant authorities, has extended powers in the EFSF. For instance the Eurogroup Working Group approves the terms and conditions of the financial assistance (Article 2(1) (a) (i) EFSF) and receives the report on their implementation (Article 3:1 EFSF). The Commission has more limited powers on the EFSF's structure than on the EFSM's structure. For example, the Commission does not conclude autonomously the terms and conditions for the financial assistance with the beneficiary Member State. A precondition for such a legitimate conclusion is the Eurogroup Working Group's approval (Article 2(1) (a) (i), (iii) EFSF).

The ESM Board of Directors is composed by one Director (and one alternative Director) appointed by each ESM Member State (Article 6 ESM). It is chaired by the Managing Director (Article 7 ESM). The Board of Directors is composed of officials of "high competence in economic and financial matters" (Article 6:1 ESM). It has the powers conferred to it by the Treaty as well as the powers delegated to it by the Board of Governors (Articles 5:6 (m), 6:6 ESM). It is responsible for the day to day business of the ESM (Article 7:5 ESM). The central role in the everyday running of the ESM has the Managing Director who is also the legal representative of ESM (Article 7:5 ESM). In the ESM the Commission has limited powers. It is assigned with operational tasks such as the negotiation of terms and conditions with the beneficiary Member State and the monitoring of the implementation. The Commission is assisted by the European Central Bank in this process. For these tasks the ESM cooperates also with the IMF (Article 38 ESM).

The structure of EFSF and ESM includes another technocrat institution next to the Commission. The involvement of another institution may make the decision-making procedure lengthier. For example the Commission negotiates the terms and conditions for the financial assistance which shall be approved by the Eurogroup Working Group and the Board of Directors in the EFSF and ESM respectively. The intergovernmental structure of the EFSF and ESM demands that the interests of the Euro area Member States are secured. The involvement of the Eurogroup Working Group and the Board of Directors is necessary in order to ensure these interests. 


\subsection{Decision-Making Process}

In the ESM the decision making process has two phases (Article 13 ESM). The first phase is the assessment whether the Applicant Member State is eligible to be granted financial assistance (Article 13:1-2 ESM). Following a positive decision for granting the financial assistance, the second phase includes the agreement on the conditions for granting the financial assistance and the conclusion of the Financial Assistance Facility Agreement (Article 13:3-5 ESM).

In the first phase, the Member State addresses a request for financial assistance to the Board of Governors and the Board of Governors is called upon deciding on the request. The requirement of the initiative by the distressed Member State is also set in the EFSF (Article 2(1) (a) EFSF). The Applicant Member State addresses the request at the Euro area Member States. Under EFSM, there is not a provision for a formal request but Article 3:1 EFSM implies that the discussions on the financial assistance start with the initiative of the Member State. This requirement is unchanged because the granting of financial assistance is accompanied by a loss of sovereignty via the agreement on the macro-economic adjustment programme.

Upon the request, the Board of Governors mandates the Commission together with the ECB to assess whether the legal requirements for granting the financial assistance are met and what the financial needs of the state are. The legal requirements are two:(a) the granting of financial assistance to one ESM Member State will safeguard the stability of the Euro area as a whole and (b) the public debt of the Applicant ESM Member State is sustainable. The first requirement does not come as a surprise. The requirement is based on the legal basis (Article 136:3 TFEU) for the establishment of ESM (Note 43). This requirement ensures compliance with Article 125 TFEU. If the public debt is not sustainable the distressed Member State will not be able to fulfil its commitments towards the creditor Member States. These Member State would take on liabilities of the distressed Member (Note 44).

For the requirement of the sustainability of the Applicant's public debt, the technical assistance of the IMF is used. Although the decision on the sustainability of the debt is designed to be an objective economic analysis, it is highly probable that the distressed Member State, as well as, all the political actors influenced by such a decision will put pressure on the Commission's assessment and report to the Board of Governors (Notes 45). However an objective economic analysis is necessary for the planning of a credible macro-economic adjustment programme. A realistic macroeconomic programme will be followed without deviations and the market accessibility will be built gradually.

If all the requirements are fulfilled, the Board of Governors will grant in principle the financial assistance at the Applicant ESM Member State and the second phase will follow. There is not a clear provision in the statute of ESM what the decision of Board of Governors should be in case that the legal requirements are not fulfilled. The model of the IMF which is followed by the ESM suggests the following reaction. In case that the assessment about the debt sustainability is negative, the Applicant State should take other measures before claiming the financial assistance of ESM. The State should negotiate a debt restructuring with its private creditors (Note 46). However this suggestion is not a legal requirement under the IMF nor ESM. If the distressed State follows this economic policy, the chances are good that the assessment about the debt sustainability of the Applicant State will be positive.

Comparing with EFSM and EFSF, there are neither certain criteria as to the eligibility of a Member State to the financial assistance nor the assignment of an institution with assessing these criteria. The criteria can be inferred from the legal basis of these mechanisms (Article 122:2 TFEU). The EFSM preamble elaborates on these requirements. In practice the assessment is done preliminary by the Commission and the ECB and the decision on the granting is included in a statement by the Council and the Eurogroup. For example, the ECOFIN and Eurogroup statement for Ireland was: "Ministers welcome the request of the Irish Government for financial assistance from the European Union and euro-area Member States. Ministers concur with the Commission and the ECB that providing assistance to Ireland is warranted to safeguard financial stability in the EU and in the euro area" (Note 47). The ESM Member States included this preliminary phase in Article 13:1-2 ESM. This inclusion provides the procedure of the decision-making with clarity and transparency.

In the ESM's second phase, the Board of Governors has the power (a)to approve the Memorandum of Understanding containing the conditions for granting financial assistance (Article 13:4 ESM) and (b) to adopt a decision on the conclusion of the Financial Assistance Facility Agreement (Article 13:3 ESM). In this phase the Board of Directors is assigned with the approval of the Memorandum of Understanding before its adoption by the Board of Governors. The Managing Director is preparing the draft Financial Assistance Facility Agreement. 
The Commission has the task of negotiating the conditions of a macro-economic adjustment programme with the Applicant State. The Commission is the negotiator in all three financial mechanisms.

The conditions of the macroeconomic adjustment programme in EFSM, EFSF and ESM are designed along the lines of an austerity policy which includes reducing expenditures and increasing taxes at the national budget planning. For example the Memorandum of Understanding for Portugal includes: "Our program is fully specified and carefully balanced between expenditure and revenue measures. The 2011 budget already entails a significant effort, with discretionary fiscal measures amounting to some 5.4 percent of GDP [...] To reach our target for 2011, we will compress some spending (0.3 percent of GDP) relative to the 2011 budget, particularly in subsidies to SOEs and health spending. Additionally, to reach the targets for 2012-13, we need to take measures of about 5 percent of GDP in 2012-13. These measures are fully specified in this MEFP at the outset. As to the policy mix, expenditure measures account for 3.5 percent of GDP and revenue measures for 1.4 percent of GDP. The priority given to expenditure measures is in line with the need to reduce the public sector's large claim on resources. The fiscal adjustment will be supported by well-specified structural reforms" (Note 48).

Economically speaking the austerity policy has been criticized for its cyclical effect. The distressed Member States have difficulties in reducing the amount of deficits and debt by following the austerity measures. These Member States fall into deeper recession. The austerity measures policy is followed by all the financial mechanisms. The establishment of ESM did not prevent the risk of the cyclical recession for the Beneficiary Member States (Note 49). Legally speaking, the austerity measures on the macroeconomic adjustment programme ensure the prevention of moral hazard and the compliance with Article 125 TFEU.

Leaving such criticism aside, once the negotiations are concluded, the Memorandum of Understanding is submitted for approval to the Board of Governors and then it is included in the Financial Assistance Facility Agreement which shall be adopted by the Board of Governors. The Board of Governors takes this decision by mutual agreement (Article 5:6 (f) ESM). Article 4:3 ESM provides that "The adoption of a decision by mutual agreement requires the unanimity of the members participating in the vote". This rule may potentially make the granting of financial assistance difficult.

All the Euro area Member States (via their Minister of Finance at the Board of Governors) shall agree on both the providing of the assistance and on the grounds of this provision. This may be a lengthy procedure in case that a Member State does not agree with the conditions laid down on the draft Memorandum of Understanding and it comes with proposals to alter or add some provisions. Furthermore the power of veto, which each Member State has, makes the decision for granting assistance highly political. Blocking the decision of granting assistance at this final step would cause uncertainty at the distressed Member States. The uncertainty about the final criteria of granting the assistance undermines the mechanism's credibility. As the Member of the European Parliament, Guy Verhofstadt mentions: "The permanent and temporary rescue funds cannot work because they have a unanimity rule. If we keep this rule, it means that the entire Eurozone will from now on be hijacked by Eurosceptic governments and by Eurosceptic political parties" (Note 50).

Article 4:4 ESM provides that the rule of "mutual agreement" is waived when "a failure to urgently adopt a decision to grant or implement financial assistance[...]would threaten the economic and financial sustainability of the Euro area". In this instance the decisions are adopted by a qualified majority of $85 \%$ of the votes cast. The emergency procedure is an innovation of the ESM Treaty which enables the ESM Members to take immediate action.

It is argued that if the qualified majority rule were applying as a general rule, the shortcomings of the veto power that the ESM Members have would be overcome. This is not an unusual voting procedure to the Member States. For example, the Ministers of Finance at the Council formation take decisions with qualified majority. The counter argument is that the application of the qualified majority voting as a general rule results in transferring sovereignty to the ESM. Such a reform to the voting demands strong political will (Note 51). The choice of the Member States to interpret broadly or narrowly a situation as a threat to the sustainability of the Euro area will determine the frequency of the resort to the emergency voting procedure. A broad interpretation of the aforementioned term will indicate the political will of the Member States to compromise in the exercise of their powers within ESM.

\section{Judicial Control: Interpretation and Dispute Settlement}

The judicial control of financial mechanisms clarifies their competences and their functions. The ruling of the judicial institution is binding and contributes to legal certainty and predictability. A financial mechanism is effective when there is no uncertainty concerning the legality of its establishment or of its bodies' acts. 
The EFSM is established by a non-legislative act of the Council. The Council is a European institution and the Council's acts are reviewed for their consistency with the Treaties. The competent institution to rule on whether the law is observed in the interpretation and application of the Treaties is the European Court of Justice (Article 19:1 TEU). The EFSM Regulation does not provide explicitly for the European Court's competence. The competence is inferred by the nature of the act establishing the EFSM.

The EFSF is established by an intergovernmental agreement. The agreement on EFSF does not establish a judicial body per se for the interpretation of the Treaty and the dispute resolution among the EFSF Members (the euro area Member States) and/or EFSF institutions. The euro area Member States agreed that: " $a$ dispute between them only, it shall be submitted to the exclusive jurisdiction of the Court of Justice of the European Union. To the extent there is a dispute between one or more euro-area Member States and EFSF, the Parties agree to submit the dispute to the exclusive jurisdiction of the Courts of the Grand Duchy of Luxembourg" (Note 52).

This attribution of power to the Court of Justice of the European Union shall be compatible with the rules establishing it. The European Court has competence to hear cases among the European Institutions or/and Member States concerning disputes arising from the application of the primary and secondary European Law (Article $263 \mathrm{TFEU}$ ) as well as giving preliminary rulings on its interpretation (Article $267 \mathrm{TFEU}$ ). The bodies of EFSF are established by the international agreement between the EFSF Members. In principle the European Court does not have jurisdiction over the acts of these bodies.

The legal basis for the European Court's jurisdiction is found in Article 273 TFEU. The Article 273 TFEU provides that the jurisdiction of the European Court is prorogated by the agreement of the Member States. The EFSF Members have agreed on this prorogation in their international agreement for the establishment of EFSF (Article 16 (2) EFSF). The agreement refers to disputes between EFSF Members. Article 273 TFEU refers only to the dispute resolution by the European Court; it does not refer to the possibility of a preliminary ruling. Furthermore, Article 273 TFEU refers only to disputes between Member States and not to disputes between Member States and institutions consisting of these Member States. These latter disputes are submitted to the exclusive jurisdiction of the Courts of the Grand Duchy of Luxembourg which is the State where the EFSF is incorporated and has its registered office.

The ESM agreement regulates the judicial control on the same basis as the EFSF agreement. The interpretation of the Treaty is assigned to the Board of Directors. Article 37:1 ESM prescribes that "any question of interpretation or application of the provisions of this Treaty and the by-laws of the ESM ... shall be submitted to the Board of Directors for its decision". The dispute resolution is assigned to the Board of Governors. Article 37:2 ESM prescribes that "The Board of Governors shall decide on any dispute arising between an ESM Member and the ESM, or between ESM Members, in connection with the interpretation and application of this ESM Treaty".

The ESM Members appoint the European Court of Justice as the competent judicial institution for the resolution of the dispute in last resort: "If an ESM Member contests the decision referred to in paragraph 2 by the Board of Governors, the dispute shall be submitted to the Court of Justice of the European Union" (Article 37:3 ESM). The European Court of Justice has competence on the basis of Article 273 TFEU. It is not clear whether Article 273 TFEU can be used as a legal basis for the disputes between the contracting parties and the ESM. The ESM has full legal personality and legal capacity to be a party to legal proceedings (Article 32:2 (c) ESM). However Article 273 TFEU refers only to disputes between Member States and not between Member States and institutions consisting of these Member States. A broad interpretation of Article 273 TFEU is needed in order the latter cases to be submitted to the European Court's jurisdiction.

\section{Conclusions}

The Member States established the EFSM in the framework of Article 122:2 TFEU and the EFSF along the same lines with the requirements of Article 122:2 TFEU. EFSM was established with the Union method and EFSF was established with intergovernmental processes. The ESM was established under Article 136:3 TFEU in the form of an international organisation. Article 122:2 TFEU prescribes Union financial assistance to a Member State under exceptional circumstances beyond Member State's control. The EFSF international agreement sets the same requirements for the financial assistance from additional contributions of the Member States. Article 136:3 TFEU prescribes financial assistance (via a financial mechanism) to a euro area Member State when the Member State's distressed economy is a risk to the financial stability of the euro area as a whole.

Article 136:3 TFEU is a broader legal basis than Article 122:2 TFEU. Article 136:3 TFEU provides the legal basis for a systemic response to the financial crisis in the euro area. However Article 136:3 TFEU fails to 
prescribe this response to the financial crisis under the Union method. The competences remain with the Member States which act outside the Union's framework. Article 122:2 TFEU provides the legal basis for Union financial assistance to a Member State. The grounds of the Union financial assistance are limited on the individual and exceptional circumstances of a Member State. The Member States failed to create a legal basis for the competences of the Union in the financial crisis management.

The structure of the ESM has the Board of Governors (Eurogroup) on top of the decision-making process. The Eurogroup has the competence to take the final decision on granting the financial assistance under certain terms and conditions. The Board of Governors is assisted by the Board of Directors which is a technocratic body. The latter takes interim decisions before the Board of Governors' final decisions. The Board of Directors is presided by the Managing Director who is responsible for the day to day operation of ESM.

The Commission plays an important role in the preparation of the Board of Governors decision but it does not have decision-taking powers. The Commission assesses the requirements for the financial assistance such as the risk to the financial stability of the euro area as a whole and the sustainability of the distressed Member State's economy. The Commission also proposes the terms and conditions in the macroeconomic adjustment programme.

The limited powers of the Commission are due to the intergovernmental nature of ESM. The comparison with EFSM shows that the Commission had more powers in the Union financial mechanism. For example, the Commission concluded the Memorandum of Understanding with the beneficiary Member State while the Council was just informed about it (Article 3:5 EFSM). The enhanced role of the Board of Governors and the Board of Directors ensures the efficiency of the ESM. Both bodies ensure that the interests of the euro area as a whole are safeguarded in every decision of the ESM. The exclusion of Council and the Commission eliminates the interference of broader interests in the decision-making process of the ESM.

The efficiency of the ESM decision-making is questioned by the unanimity required to reach a decision on the financial assistance by the Board of Governors. The Member State which does not agree with the conditions laid down on the draft Memorandum of Understanding can propose changes or additions. Furthermore the power of veto, which each Member State has, makes the decision for granting assistance highly political and cause uncertainty at the distressed Member States. The Member States have introduced a rule on emergency decisions taken by qualified majority. It remains to be seen how often they would recourse to this rule which eliminates the risks of the unanimity rule.

The European Court of Justice is competent to rule on disputes concerning the ESM Members or the ESM Members and the ESM. The judicial control ensures the legality of the ESM. The trust on the legality of the ESM reinforces the ESM's credibility. A legitimate and credible financial mechanism has the political support of the Member States. This facilitates the decision-making and makes the ESM an effective financial mechanism. The judicial review of ESM was assigned to the European Court of Justice. Although the ESM is an intergovernmental organisation, it is established in consistency with the European law. The European Court is the only pertinent judicial institution to rule in this consistency.

\section{References}

Athanassiou, P. (2011). Of past measures and future plans for Europe's exit from the sovereign debt crisis: what is legally possible (and what is not). European Law Review, 36(4), 558-575.

BVerfG, 2 BvR 987/10 dated 07.09.2011, paragraph no (1-142), Decision of the German Constitutional Court. Retrieved from http://www.bverfg.de/entscheidungen/rs20110907_2bvr098710.html

Editorial Comments. (2012). Some thoughts concerning the Draft Treaty on a Reinforced Economic Union. Common Market Law Review, 49, 1-14.

Council of the European Union. (2010, May 10). Annex: Decision of the Representatives of the Governments of the Euro Area Member States Meeting Within the Council of the European Union.

Council of the European Union Press. (2010, May 9/10). European stabilisation mechanism to preserve financial stability.

Council of the European Union. (2011, July 21). Statement by the Heads of State or Government of the euro area and $E U$ institutions. Retrieved from http://www.consilium.europa.eu/uedocs/cms_data/docs/pressdata/en/ec/123978.pdf

De Grauwe, P. (2011). Financial assistance in the euro zone: why and how? Journal for Institutional Comparisons, 9(3), 26-30. 
De Witte, B. (2011). The European Treaty Amendment for the Creation of a Financial Stability Mechanism. Swedish Institute for European Policy Studies, (6), 1-8.

Council of the European Union. (2010, May 10). On the Decision of the Representatives of the Governments of the Euro Area Member States Meeting within the Council of the European Union and on the Decision of the Representatives of the Governments of the 27 EU Member States.

ECOFIN. (2010, May 9/10). Press Release 9596/10 (Press 108).

EFSF. (2010, June 7). EFSF Framework Agreement of 7 June 2010 between the euro area Member States and the EFSF (as amended with effect from the Effective Date of the Amendments). Retrieved from http://www.efsf.europa.eu/attachments/20111019_efsf_framework_agreement_en.pdf

EFSF. (n. d.) Commitments and Lending Capacity. Retrieved from http://www.efsf.europa.eu/attachments/efsf_commitments_and_lending_capacity.pdf

EFSF. (2011, November 29). Guideline on interventions in the secondary market. Retrived from

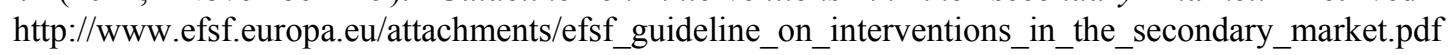

EFSF. (2011, November 29). Guideline on Precautionary Programme. Retrieved from

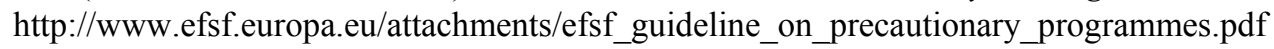

EFSF. (n. d.). Guideline on Recapitalisation of Financial Institutions (FIs) via loans to non-programme countries. Retrieved from http://www.efsf.europa.eu/attachments/efsf_guideline_on_recapitalisation_of_financial_institutions.pdf

EFSF. Investors Relations. Retrieved from http://www.efsf.europa.eu/investor_relations/index.htm

EFSF. Lending operations. Retrieved from www.efsf.europa.eu/about/operations/index.htm

European Commission. (2010, May 10). On the European Stabilization Mechanism. Retrieved from http://europa.eu/rapid/pressReleasesAction.do?reference=MEMO/10/173

European Central Bank. (2011). The European Stability Mechanism. ECB Monthly Bulletin, July, 71-84.

European Council Conclusions, 16-17 December 2010, EUCO 30/1/10 REV1, CO EUR 21, CONCL 5

European Council Conclusions, 24-25 March 2011, EUCO 10/1/11 REV 1, CO EUR 6, CONCL 3

European Council Conclusions, 28-29 October 2010, EUCO 25/1/10 REV1, CO EUR 18, CONCL4

European Council Decision, 25 March 2011, 2011/199/EU

European Parliament. (Debate on 2010, December 15). Preparations for the European Council meeting (16-17 December 2010) - Establishing a permanent crisis mechanism to safeguard the financial stability of the euro area. $\quad$ Retrieved from http://www.europarl.europa.eu/sides/getDoc.do?type=CRE\&reference=20101215\&secondRef=ITEM-005 $\&$ format $=$ XML \&language $=\mathrm{EN}$

European Parliament. (Debate on 2011, February 15). Adoption of Modifications to Treaty. Retrieved from http://www.europarl.europa.eu/sides/getDoc.do?type=CRE\&reference=20110215\&secondRef=ITEM-012 $\&$ format $=$ XML \&language $=\mathrm{EN}$

European Parliament. (Debate on 2010, May 19). Outcome of the summit of 7 May 2010 and the ECOFIN meeting. Retrieved from http://www.europarl.europa.eu/sides/getDoc.do?type=CRE\&reference=20100519\&secondRef=ITEM-003 $\&$ format $=\mathrm{XML} \&$ language $=\mathrm{EN}$

European Parliament. (Debate on 2011, April 5). Conclusions of the European Council meeting (24-25 March 2011). Retrieved from http://www.europarl.europa.eu/sides/getDoc.do?type=CRE\&reference=20110405\&secondRef=ITEM-003 $\&$ format $=$ XML\&language $=\mathrm{EN}$

Fuest, C. (2011). Will the reform of the institutional framework restore fiscal stability in the eurozone? Ifo Institute for Economic Research (CESifo Forum), 12(2), 34-39.

Gros, D., \& Mayer, Th. (2011). EFSF 2.0 or the European Monetary Fund. CESifo Journal for Institutional Comparisons, 9(3), 31-37.

Hufeld, U. (2011). Between emergency aid and Rutli Shwur: The reconstructing of the Economic and Monetary Union in times of economic crisis. Journal of Studies on European Integration and Federalism, (361), 53-72. 
Louis, J. V. (2010). Guest Editorial: the no-bailout clause and rescue packages. Common Market Law Review, 47, 971-986.

Micossi, S., Carmassi, J., \& Peirce, F. (2011, March 8). On the tasks of the European Stability Mechanism. Centre for European Policy Studies (CEPS) policy brief, 235, 1-11.

Pringle C-370/12, ECJ (European Court of Justice), pending.

Pringle Th. (2012, July 31). v The Government of Ireland, Ireland and the Attorney General [2012] IESC 47 Irish Supreme Court. Retrieved from http://www.bailii.org/ie/cases/IESC/2012/S47.html

Recker, S. (2011). Case note-Euro Rescue Package Case: The German Federal Constitutional Court Protects the Principle of Parliamentary Budget. German Law Journal, 12(11), 2071-2075.

Regulation (EU) 407/2010 of Council of 11 May 2010 establishing a European financial stabilisation mechanism [2010] L118.

Ruffert, M. (2011). The European debt crisis and European Union Law. Common Market Law Review, (48), 1777-1806.

Statement by the Eurogroup and ECOFIN Ministers. (2010, November 11). Retrieved from http://www.consilium.europa.eu/uedocs/cms_data/docs/pressdata/en/ecofin/117898.pdf

Statement by the Heads of State or Government of the European Union. (2010, February 11). Retrieved from http://www.consilium.europa.eu/uedocs/cms_data/docs/pressdata/en/ec/112856.pdf

Statement by the Heads of State or Government of the European Union. (2010, March 25). Retrieved from $\mathrm{http} / / / \mathrm{www}$. consilium.europa.eu/uedocs/cms_data/docs/pressdata/en/ec/113563.pdf

Statement of the Heads of State or Government of the Euro Area. (2010, May 7). Retrieved from http://www.consilium.europa.eu/uedocs/cms_data/docs/pressdata/en/ec/114295.pdf

The Economic Adjustment Programme of Portugal. June 2011. Directorate-General for Economic and Financial Affairs. Occasional $\quad$ Paper, $79 . \quad$ Retrieved from http://ec.europa.eu/economy_finance/publications/occasional_paper/2011/pdf/ocp79_en.pdf

Treaty establishing the European Stability Mechanism. (2012). Brussels. Retrieved from http://www.efsf.europa.eu/attachments/esm_treaty_en.pdf

\section{Notes}

Note 1. Statement of the Heads of State or Government of the Euro area, 7 May 2010

Note 2. ECOFIN, 9/10 May 2010

Note 3. Council Regulation 407/2010

Note 4. EFSF Framework Agreement

Note 5. The first disbursement for Ireland was on February 1, 2011, for Portugal on June 22 2011. EFSF: Lending operations: www.efsf.Europa.eu/about/operations/index.htm

Note 6. EFSF remaining lending capacity $€ 440$ bn $-€ 192$ bn $=€ 248$ bn www.efsf.Europa.eu/attachments/efsf_commitments_and_lending_capacity.pdf. See also: Gros D., Mayer T. 2011, p. 33

Note 7. EFSF Framework Agreement Article 2(11)

Note 8. European Council Conclusions, 24-25 March 2011

Note 9. Treaty establishing the European Stability Mechanism

Note 10. Not to be confused with the European Stability Mechanism, which was to be founded later and which is the subject of this paper

Note 11. ECOFIN, 9/10 May 2010

Note 12. European Commission MEMO /10/173 of 10 May 2010

Note 13. Council Regulation (EU) No 407/2010 of 11 May 2010, preamble (2)-(4)

Note 14. BVerfG, 2 BvR 987/10 dated 07.09.2011, paragraph no (41). See also: Hufeld U. 2011. 53; Recker S. 2011, p. 2073. 
Note 15. ECOFIN, 9/10 May 2010

Note 16. EFSF Framework Agreement (as amended), preamble (1)

Note 17. For example the Council shares the legislative power with the European Parliament

Note 18. European Parliament debates, 15 December 2010

Note 19. European Parliament debates, 15 February 2011

Note 20. EFSF Framework Agreement (as amended), para 16:1

Note 21. Louis Jean-Victor, 2010. p. 976-978

Note 22. De Witte Bruno, 2011. p. 6

Note 23. Athanassiou, Phoebus, 2011, p. $561 \& 563$

Note 24. The legality of the new mechanism was challenged by an action lodged with the Irish Courts. The Irish Supreme Court referred a preliminary ruling on the European Court of Justice.

Note 25. European Council Conclusions, 28-29 October 2010, point I: 2

Note 26. Supra 28-29 October, point I: 1

Note 27. Supra note De Witte

Note 28. European Council Conclusions, 16-17 December 2010, point I:2

Note 29. Président de la Commission européenne,"Avis de la Commission Européenne sur le projet de modification de l'article 136 du Traite", 15 February 2011, Speech 11/105

Note 30. European Parliament, Note of 6 July 2012, p. 10

Note 31. See Ruffert M, 2011, p 1789

Note 32. European Council Decision, 25 March 2011, Article 1

Note 33. Micossi S., 2011, p.4

Note 34. Pringle Thomas v The Government of Ireland, Ireland and the Attorney General [2012] IESC 47 (31 July 2012), VI

Note 35. Pringle Case C-370/12, pending

Note 36. European Council Conclusions, 24-25 March 2011, Annex II "institutional form"

Note 37. Supra note 25 March, Article 2

Note 38. Supra note Note of 6 July, p. 5

Note 39. Editorial Comments Common Market Law Review, 2012, pp.1-2

Note 40. De Witte, 2011, p. 8

Note 41. Louis J-V, p. 985; Ruffert M. p. 1789

Note 42. European Parliament debates, 19 May 2010

Note 43. See also 2.2

Note 44. Micossi S. 2011, p. 9

Note 45. Fuest C. 2011, p. 37

Note 46. ECB, Monthly Bulletin, 2011, p. 79

Note 47. Statement by the Eurogroup and ECOFIN Ministers, 21 November 2010

Note 48. Micossi S. 2011, p. 9

Note 49. Fuest C. 2011, p. 37

Note 50. ECB, Monthly Bulletin, 2011, p. 79

Note 51. Statement by the Eurogroup and ECOFIN Ministers, 21 November 2010

Note 52. EFSF Framework Agreement, Article 16 (2) 


\section{Copyrights}

Copyright for this article is retained by the author(s), with first publication rights granted to the journal.

This is an open-access article distributed under the terms and conditions of the Creative Commons Attribution license (http://creativecommons.org/licenses/by/3.0/). 